\begin{tabular}{cc} 
Coğrafi Bilimler Dergisi & Cografi \\
Bilimler & Dergisi \\
\hline & Turkish Journal of Geographical Sciences \\
\hline
\end{tabular}

\title{
Toplumsal Cinsiyetin, Mekânın ve Zamanın Tektipleştirilmesi: Tecavüz İçerikli Karikatürler ve Gerçek Temsiller Üzerine Bir Araştırma
}

\author{
Monotyping gender, place and time: a study on rape caricatures and real life \\ portrayals
}

\section{Muhammet Öksüz*a, Ayla Deniz ${ }^{\mathrm{b}}$}

\begin{tabular}{l} 
Makale Bilgisi \\
\hline DOI: \\
10.33688/aucbd.559283 \\
\hline Makale Geçmişi: \\
Geliş: 18.09.2018 \\
Kabul: 28.03.2019 \\
\\
\hline Anahtar Kelimeler: \\
Tecavüz \\
Karikatür \\
Temsil \\
Haber \\
Gerçeklik
\end{tabular}

\begin{tabular}{l} 
Article Info \\
\hline DOI: \\
10.33688/aucbd.559283 \\
\hline Article History: \\
Received: 18.09 .2018 \\
Accepted: 28.03.2019 \\
\hline Keywords: \\
Rape \\
Caricature \\
Representation \\
News \\
Reality
\end{tabular}

\begin{abstract}
$\ddot{O} z$
Bu çalışmada, tecavüz içerikli karikatürlerde toplumsal cinsiyet ve mekân ilişkilerinin kurgulanma biçimleri ele alınmaktadır. Aynı zamanda bu ele alışla ortaya çıkan görünümün, gerçek mağdurların deneyimleriyle karşılaştırılması amaçlanmaktadır. Bu yolla karikatürlerdeki içerikle gerçeklik arasındaki ilişkinin nasıl olduğu ve bunu yaratan bă̆lam belirginleştirilmeye çalışılmaktadır. Bu kapsamda 80 karikatür ve tecavüzle ilgili 150 haber incelenmiştir. Bu çalışmanın sonucunda, tecavüz karikatürlerinde faillerin ve măgdurların tektipleştirildiğ $i$ ve belirli grupları işaret ettiği görülmüştür. Gerçek măgdurlara ilişkin taranan haberlerde ise bu tektipleştirmenin olmadığl, daha çeşitli grupların tecavüzün tarafları olduğu anlaşılmıştır. Yine karikatürde tecavüz mekânları olarak kamusal mekânlar gösterilmektedir. Bununla birlikte, gerçek tecavüz örneklerinde özel alanda tecavüzün daha fazla gerçekleştiği görülmüştür. Dolayıslyla tecavüz içerikli karikatürlerin bu haliyle toplumsal cinsiyet eşitliğine ve sosyal adalete hizmet etmediği gibi var olan toplumsal cinsiyet rollerini pekiştirdiği, toplumsal cinsiyet eşitsizliğini güçlendirdiğ $i$ ve bunları yeniden ürettiği anlaşılmıştır.
\end{abstract}

\footnotetext{
*Sorumlu Yazar/Corresponding Author: muhammetoksuz@siirt.edu.tr

a Siirt Üniversitesi, Coğrafya Bölümü, Siirt, Türkiye, https://orcid.org/0000-0002-2255-3111

b Ankara Üniversitesi, Coğrafya Bölümü, Ankara, Türkiye, https://orcid.org/0000-0001-5964-0131
} 


\section{Giriş}

Karikatürler, kişilerin ve toplumların önemli hafıza bileşenlerindendir ve hem görsel kültürü yansıtıcı hem de onu yeniden üretici işlevi görürler. Türk Dil Kurumu, görsel kültürün önemli bir ögesi olan karikatürü 'insan ve toplumla ilgili her tür olayı konu alarak abartılı bir biçimde veren, düşündürücü ve güldürücü resim' şeklinde tanımlamaktadır'. Bu haliyle karikatürün toplumsal gerçekliğin bilinçli olarak çarpık çizimi olduğu anlaşılmaktadır. Zaten karikatür sözcüğünün kökeni İtalyanca doldurmak, yüklemek; mecazî olarak da abartmak, alay etmek anlamına gelen 'caricare' sözcüğünden gelmektedir (Yengin, 2010). Bunun yanında, duygu ve düşüncelerin doğala ters düştüğü (Alsaç, 1994), sorunun var olduğu yerde mizahın var olması gerektiği ve sorunun gerçek nedenlerini irdelediği (Karakuş, 2012), gerçeğin sahte yanını ortaya koyduğu (Hilav, 1994: 19), bireyin düşünce dünyasında sarsıntılara sebep olduğu (Şahin, 2014), içtimai silah olan yazıdan ve şiirden daha güçlü olduğu (Kar, 1999) gibi ifadeler de karikatürü tanımlamak için kullanılmıştır. Buradan hareketle karikatürlerde abartılı bir çizim, güldürme, eğlendirme, çarpıtma, yapı bozum yapma, düşündürme, eleştirme, saldırma, gerçekliği ortaya koyma vb. işlevler de aranmaktadır. Fakat yine de bir karikatürde bunların tamamının olması beklenmez. Nitekim sadece güldürme ve eğlendirme amaçlı karikatürler olduğu gibi düşündüren ve güldüren karikatürler de vardır. Hatta bütün bunlardan öte, statükoyu, toplumsal normları, siyasal, dinsel ve toplumsal iktidarı besleyen karikatürlerde oldukça yaygınlaşmaya başlamıştır. Bunun nedeni karikatürün gücünün farkına varılmasıdır. Nitekim İsmail Kar (1999) karikatürün gücünün resim ve yazının önüne geçtiğini ve büyük halk kitlelerini etkilemek için en kısa yol olduğunu belirtmektedir. Bütün bu kullanım şekillerini yaratan tarihsellik içinde karikatürün temelinin mağara duvarlarındaki abartılı çizimlere dayandırılma eğilimi olsa da onun asıl gelişimi matbaanın yaygınlaşmasıyla mümkün olmuştur. Bu sayede basılı ürünler içinde karikatür gelişme imkânı bulmuştur. Bu gelişim içinde karikatürlerde içerik zenginleşmesi yaşanmıştır. Toplumu ilgilendiren, onun var ettiği ve onu var eden olaylar karikatür konusu haline gelmiştir. Bunlardan biri de tecavüzdür.

Karikatürlere konu olan tecavüzün bizatihi kendisi toplumsal iktidarın dışavurumudur. Mehrhof ve Kearon'un (1973: 233) tecavüzü, 'etkili bir politik araç' olarak tanımlamaları da bununla ilgilidir. Dolayısıyla tecavüz, bir bireyin bir başkasına karşı uyguladığı keyfi bir şiddet hareketi değildir; politik bir baskı altına alma eylemidir ve güçlü bir sınıfın üyeleri tarafından, güçsüz bir sınıfın üyelerine karşı uygulanır (Donovan, 2016). Bu bakımdan, tecavüzün mağdurlarının çoğunun kadın olması, politik baskının kadınlara yönelik olduğunu ve kadınların toplumun güçsüz sınıfının üyeleri olarak görüldüklerini göstermektedir. $\mathrm{Bu}$ bilgiler 1şı̆̆ında tecavüz karikatürlerinde tecavüzcünün ve mağdurun nasıl temsil edildiği, tecavüze yönelik politik tutumu görmek açısından önemlidir. Bunların yanında tecavüz karikatürlerinin hangi mekânları içerdiği de önemlidir. Çünkü tecavüz karikatürleri sadece toplumsal cinsiyete ilişkin tiplemeler üzerinden değil, tecavüzün gerçekleştiği mekânlar üzerinden de çeşitli mesajlar vermektedir. Bu mesajlar, mekânın toplumsal cinsiyetiyle ilgilidir ve tecavüzün, bazı mekânlara ilişkin cinsiyetçi sınırların ihlalinin bir sonucu olarak görülmesine yol açabilmektedir. Bununla birlikte, doğrudan bu ilişkileri açığa çıkarmayı deneyen çalışmalardan yoksunluk, bunların bilinmesini engellemektedir. Bu çalışmanın yapılma gerekçesi, bu ilişkileri içeren bir tartışma geliştirmektir. Bu tartışmayı derinleştirmek için, karikatürler 
yanında gerçek mağdurların hikâyelerini içeren haberlere ilişkin bir tarama yapılmıştır. İlgili konulardaki çalışmalardan (Okray, 2018) bu çalışmanın farkı, karikatürü ve gerçek hayattan kesitleri birlikte değerlendirmesidir.

Bu çalışma temelde 3 kısımdan oluşmaktadır. Birinci kısımda, tecavüz, toplumsal cinsiyet ve mekân (bağlantılı olarak zaman) ilişkisine dair bir tartışma yapılmaktadır. İkinci kısımda, tecavüz karikatürlerinde toplumsal cinsiyet ve mekânın (ilişkili olarak zamanın) nasıl ele alındığına yer verilmektedir. Üçüncü kısımda, gerçek mağdurlar üzerinden yapılan değerlendirme paylaşılmaktadır.

\section{Tecavüz, Toplumsal Cinsiyet ve Mekâna İlişskin Bir Değerlendirme}

Dünya Sağlık Örgütü (WHO, 2002: 149-150) Şiddet ve Sağlık Konulu Dünya Raporunda cinsel şiddet türlerini on bir başlık altında toplamıştır. Bunlar evlilik ve beraberliklerde gerçekleşen tecavüz, yabancılar tarafından gerçekleştirilen tecavüz, savaş sırasında gerçekleştirilen sistematik tecavüz, cinsel birleşmede bulunmaya yönelik istenmeyen cinsel sataşmalar ve saldırılar, zihinsel veya fiziksel olarak engelli bireylerin cinsel istismarı, çocukların cinsel istismarı, zorla evlendirme (çocukların evlendirilmesini de içermektedir), gebelikten ya da cinsel yolla bulaşan hastalıklardan korunma yöntemlerini kullanma hakkının engellenmesi, zorla düşük yaptırma, kadının cinsel bütünlüğüne yönelik saldırgan eylemler (zorla yapılan kızlık zarı ve bekâret muayenelerini içermektedir), cinsel istismar amacıyla zorla fuhuş ve insan kaçakçıllğıdır. Bunlar içinde tecavüz, cinsel şiddet içinde en yaygın türlere karşılık gelmektedir. Bu nedenle de tecavüz, dünya çapında ciddi bir sorun olarak görülmektedir (Bohner vd., 2002: 257). Peki, tecavüz nasıl tanımlanmaktadır? Catherine MacKinnon (2015: 199-203), tecavüz ile ilgili yapılan yasal tanımlamaların çoğunlukla penisin veya herhangi bir cismin bir yere girişi olarak tanımlandığını ve bunun bile eril bir bakışı yansıttığını ifade etmektedir. Dolayısıyla eylemin kendisi şiddet içerdiğinden ve şiddet eril tahakkümün ve iktidarın meşrulaştırma aracı olduğundan cinsel şiddet üzerinden üstünlük yaratılmaktadır. Bu noktada sorulması gereken ikinci soru tecavüzün taraflarının kimler olduğudur. Tecavüze ilişkin bildirilen vakaların çoğunda kadınlar mağdur, erkekler ise fail olarak yer almaktadır (Poppen ve Segal, 1988). Bu bilgiler 1şığında tecavüzün taraflarının nasıl değerlendirildiğini açığa çıkarmak için tecavüz mitlerine bakmak gerekmektedir. Bireysel inançlar olmanın ötesinde birer sosyal norm işlevi taşıyan tecavüz mitleri (Eker ve Erdener, 2011), cinsiyet ilişkilerinden ve iktidar yapılarından etkilenmektedir (Yancı vd., 2018: 108). Bu mitler, tecavüz, tecavüzcü ve tecavüz mağduru hakkında sahip olunan önyargılı, kalıplaşmış ya da yanlış inançlar olarak tanımlanır (Eker ve Erdener, 2011: 60). Bohner vd., (1998), bu mitlerin tecavüz hakkında betimleyici inançlar olduğunu ve erkeklerin kadınlara yönelik cinsel saldırganlığını inkâr etme, önemsizleştirme veya haklı göstermeye hizmet ettiğini belirtmektedir. Burt (1980) ise, bu mitlerin ortak noktasının tecavüz mağdurlarına karşı düşmanca bir iklim yaratmak olduğunu ortaya koymaktadır. Hatta bu mitlerle, tecavüzün sorumluluğu kadına yüklenmektedir ${ }^{3}$. Ayrıca tecavüz mitlerinin kabulü arttıkça, cinsel taciz kurbanına atfedilen suçlama isteğini de artmaktadır (Kooper, 1996). Bu tespitlere konu olan tecavüze ilişkin bazı mitler şu şekildedir: Kadın arandı, bunu kadın istedi, erkek bunu yapmayı istemezdi, tecavüz sıradan bir olaydır, kadın yalan söylüyordur, tecavüz sapkın bir olaydır, bu gerçek bir tecavüz değildir (Payne vd., 1999). 
$\mathrm{Bu}$ görünümde tecavüz mitlerinin nasıl kabul edildiğini anlamak önemlidir. Tecavüz mitlerinin kabul edilmesine ilişkin öncüller oldukça çeşitlidir. Bunlardan birisi tutum değişkenleridir. Tutum değişkenleri içinde cinsiyet rollerine ilişkin kalıpyargılar, cinsel muhafazakârlık, düşmanlık içeren cinsel inançlar ve kişilerarası şiddetin kabulü yer almaktadır. Kişilik değişkenleri içinde cinsiyet rolü tatmini, cinsel rol tatmini ve özsaygı yer almaktadır. Deneyim değişkenleri içinde şiddete maruz kalma, önceki mağduriyet deneyimi, kendini mağdur etme, ailede şiddetin ifadesi ve medya yer almaktadır. Temel değişkenler ise yaş, eğitim ve mesleki durumdur (Burt, 1980). Bu çok yönlü yap1 içinde hukukun tecavüze nasıl baktığı oldukça önemlidir. Bu konudaki çalışmasında Karacan (2015: 113), tecavüzün yakın geçmişe kadar çeşitli hukuk düzenlerinde ahlaka aykırı suç olarak düzenlendiğini, tecavüzün kadınların iffetlerine ve ailelerindeki erkek üyelerin şereflerine yönelik cinsel saldırı olarak kabul edildiğini ama tecavüz mağdurlarının bizzat kendilerine yönelik bir suç olarak görülmediğini, hatta yalnızca yabancı erkelerin yabancı kadınlara tecavüz edebileceğinin farz edildiğini belirtmektedir. Bunun yanı sıra kadınların tecavüz sırasında direnmeleri karşısında gördükleri şiddetin izleri, onların rıza göstermemelerinin delili olarak görülmemekte, şiddetin izi yoksa direniş göstermedikleri düşünüldüğü gibi onların rıza gösterilen bir ilişki yaşadıklarına yorulmaktadır (Kırbaş-Canikoğlu, 2013). Dolayısıyla tecavüz mitlerine ilişkin sosyal bağlamın hukuki yapıyı da şekillendirdiği söylenebilir.

Bütün bu bilgiler 1şığında tecavüz failleri için neler söylenebilir? $\mathrm{Bu}$ sorunun cevabını çalışmanın bağlamıyla da ilişkili olarak Türkiye'de aradığımızda karşımıza cezaevi kayıtları çıkmaktadır. Bu kayıtlar üzerinden yapılan bir araştırmada (Tülü, 2010), 106 tecavüz suçlusu, 157 çocuk cinsel istismar suçlusu ile görüşülmüştür. $\mathrm{Bu}$ sonuçlara göre tecavüzcülerin çoğunluğu askerliğini yapmış, bekâr kişilerden oluşmaktadır. Eğitim seviyesi oldukça düşük (ilkokul bitirmemiş), babanın evde anneye şiddet uyguladığı bir ortamda sosyalleşen, daha önce birine şiddet uyguladığ için hüküm giymiş, tecavüz mekânı olarak akşam saatlerini tercih eden, tecavüzü planladığı kişiyi eve çağırdığında gelmediğinde sinirlenen, tecavüz fiilini gerçekleştireceği mekânın 1ssız, bilindik, yakın bir yer olmasını tercih eden bir tipleme ortaya çıkmaktadır. Ve bu kişiler çevreleri tarafından kendi halinde, yalnız, yardım sever ve uyumlu olarak tanımlanmaktadırlar. Bu görünüm tecavüzün alt sınıftaki erkeklere statü kazandıran bir davranış olarak ortaya çıktığı fikrine hizmet edebilir (Özdemir, 2010: 71). Ancak bu tipolojiler genellemeye uygun mudur? Bu tipolojiler genelde kamusal alanda duyulmuş, failleri tutuklanmış olanlar üzerinden belirlenmektedir. Fakat cinsel suçların ana grubunu oluşturan cinsel taciz ve cinsel tecavüz eylemlerinin \%15-20 gibi çok küçük bir oranının adli makamlara yansıtıldığı bilinmelidir (Düvenci, 2004). Dolayısıyla adli vaka haline gelen olaylar haberlerde yer bulmaktadır. Bununla birlikte sapkın veya suçlu ilan edilmek bir iktidar ilişkisini ve iktidarın üretimini içerir. Yani suçlu olarak tanımlanan kişilerin hapiste oluşunun sınıfsal bağlamı vardır. Çünkü yasaların bazı gruplara diğer gruplara göre daha fazla uygulanma eğilimi vardır. $\mathrm{Bu}$ sebeple suça ilişkin bilgilerimizin hapiste yatan kişilerden oluşuyor oluşu sakıncalıdır. Aslında hapistekiler amatörleri kapsadığı için dengesiz bir örneklem içerirler. Eylemi yapanlar ile yapmış olmaktan yakalananlar aynı kişiler olmadığı gibi eylemi yaptığı halde yakalanmamış kişiler de söz konusudur (Becker, 2015). Bu nedenle ilgili konuda genel tipolojiler oluşturmak kolay değildir. Bununla birlikte bugün pek çok kişinin zihnindeki 'tecavüzcü' imajının birçok ortak unsuru içermesinde, görsel kültürde belirli tipolojilerin yeniden üretilmesinin etkisi vardır. 
Son olarak, toplumsal cinsiyet ilişkileriyle şekillenen tecavüzün mekânla da ilişkisi vardır ki zaten Tülü’nün (2010) çalışmasında tecavüz için bazı özellikleri taşıyan mekânların seçilmesi de bunu göstermektedir. Mekân neden önemlidir? Çünkü mekân zihinsel olanla kültürel olanı, toplumsalla tarihsel olanı birbirine bağlar (Lefebvre, 2016: 25). Bu özelliklerle şekillenen toplumsal mekan, 'toplumsal yeniden üretim ilişkilerini, yani ailenin özgül örgütlenmesiyle birlikte, cinsiyetler, yaşlar arasındaki biyolojik-fizyolojik ilişkileri ve üretim ilişkilerini, yani iş bölümünü ve örgütlenmesini, dolayıslyla hiyerarşikleşmiş toplumsal işlevleri içerir". Bu sistemin bir ürünü olarak mekânlar toplumsal cinsiyetlidirler. Bu cinsiyetli ayrım içinde özel mekân kadınlara, kamusal mekân erkeklere tahsis edilmiştir. Dinin ve geleneğin buyruklarıyla dayatılan taassup ve ahlak anlayışları da bu bölümlemeyi desteklemektedir ve kadının mekânsal hareketliliğin rotasını belirlemektedir (Cantek, vd. 2017: 122-123) ${ }^{4}$. Kadınların bütün özgürlüklerinin temelinde yer alan hareket özgürlügünü kısıtlayan bu durum, kadınlara evlerinin dışında oldukları her an tetikte olmaları gerektiği imasını yapmaktadır. Bu şekilde sadece dışarıyı doğası gereği tehlikeli olarak inşa etmekle kalmaz ayrıca evin de güvenli olduğunu iddia etmektedir. Böylece eğer kadınlar kadınsı bir saygınlığa erişmek istiyorlarsa ya evde kalmak zorundadırlar ya da toplum içinde nasıl davrandıklarına ve göründüklerine dikkat etmek zorundadırlar (Amed, 2015: 92). Bu ilişkiler içinde tecavüzün mağduru olan kadınlar, tecavüze uğradıkları yerde bulunmaları bakımından eleştirilirler. Bu bir bakıma bireyselleşen ve özgürleşen kadına karşı bir sindirme politikasıdır ve bu politikanın hızla karşılık bulduğu pek çok coğrafya vardır. Mesela Kanada'da gerçekleştirilen ulusal çaplı bir anket çalışmasının sonuçlarına göre, kadınların \%60'1 gece tek başına yürümekten, \%80'i akşam olduktan sonra toplu taşım araçlarını kullanmaktan, \%83'ü araç park bölgesindeki arabalarına tek başlarına yürümekten korkmaktadırlar (Koss vd. 1997: 233'den aktaran Özdemir, 2010). Bunun yanında Godenzi (1992: 30) tarafından yapılan araştırmaya katılan kadınların her beşinden dördü karanlıkta tenha sokaklarda beklemekten ya da arabaya el kaldırmaktan çekinmekte; \%60'dan fazlası karanlıkta otobüs duraklarında ya da istasyonlarda durmamayı tercih etmekte; postacı, pazarlamacı ve benzeri erkeklerin eve girmelerine müsaade etmemekte; yarısı az sayıda kişinin bulunduğu tren kompartımanlarına veya otobüslere binmekten kaçınmakta; her üçünden biri gündüz bile tenha bölgelerden geçmemeye çalışmaktadır. Ayrıca Etiyopya'da yaşayan mülteci kadınların, ateş yakmak amacıyla kullanılan odunları toplarken tecavüze uğramaktan korktukları için çocuklarına hazırladıkları öğünleri azalttıkları gözlenmiştir. Yine Hindistan'ın Gujarat bölgesinde kadın sağlık görevlileri, tecavüze uğramaktan korktukları için köyler arasında tek başlarına seyahat etmekten çekindiklerini bildirmişlerdir (Koss vd. 1997: 233'den aktaran Özdemir, 2010). Ayrıca kutsal kitaplarda da mekân kullanımı ve tecavüz ilişkisine bakış, kadınların aleyhindedir. Mesela Tevrat'ta ${ }^{5}$ tecavüze maruz kalan bir kadın için iki farklı mekân üzerinden bir karar verilmesi gerektiği yer almaktadır. Eğer bir kadın kent mekânında tecavüze maruz kalmışsa, kadının ve erkeği kentin kapısına götürülüp taşlayarak öldürülmesi gerektiği yazılmaktadır. Eğer bir kadın kırda tecavüze maruz kalmışsa, sadece tecavüz eylemini gerçekleştiren erkek öldürülmelidir. Bu iki farklı mekân ve karar şöyle gerekçelendirilmektedir: Kadın kentte olduğu halde yardım istemek için bağırmamıştır. Bu ifade, bağırıp bağırmamanın rızaya gönderme yaptığını göstermektedir. Aynı zamanda karikatürlerde doğaya işaret eden mekânlar, bağırılsa da duymayı mümkün kılacak mekânlar 
olmadığından, kadının beyanının dışında şahitliği de ihtimal dışı bırakır. Bütün bu bileşenlerle şekillenen tecavüz gerçeği, kadınları erkeklere bağımlı ve erkeğin kontrolünde olan ilişkiler kurmaya zorlamaktadır ki bu yüzden kadınlar, onlara yönelen tecavüzün yaygın olarak gerçekleştiği -ama görmezden gelinen- özel alana kapanmaktadırlar (Radford, 1987: 33).

Bütün bu bilgiler 1şığında bu makalede üç sorunun cevabı aranmaktadır:

1. Tecavüz karikatürlerde insan tipolojileri ve mekânlar (ilişkili olarak zaman) nasıldır?

2. Tecavüz haberlerinde insan tipolojileri ve mekânlar (ilişkili olarak zaman) nasıldır?

3. Bu ikisini birlikte değerlendirdiğimizde karşımıza ne çıkar?

\section{Materyal ve Yöntem}

Çalışma kapsamında dergi ve internet adresi (Leman, Penguen, Gırgır, Misvak ve konu ile ilgili karikatür yayını bulunan internet adresleri) ${ }^{2}$ kısıtlanmaksızın 2013-2017 yılları arasını kapsayan bir tarama yapılmış ve bu tarama sonucunda ulaşılan 80 karikatür incelenmiştir. Bunlardan doğrudan tecavüzle ilgili olan 30 ’u bu bağlamda, diğerleri de tecavüz karikatürlerindeki tiplemelerin konumlandırılmasında kullanılmıştır. Ayrıca her ne kadar gerçeği tam olarak yansıtmasa da tecavüzün kamu gündemine yansımalarını anlamak için 150 tecavüz haberi incelenmiştir. Haber sitesi olarak Hürriyet gazetesinin internet sitesi tercih edilmiştir. Karikatür örneklemini belirlerken salt bir derginin tercih edilmeyip çeşitlendirilme yapılmasına rağmen gazetede tek bir gazetenin tercih edilmesinin nedeni, bir haberin farklı gazetelerde aynen şekilde yer almasıdır. Bu nedenle bunlar içinde basılı tirajı en yüksek olan Hürriyet gazetesi tercih edilmiştir. Bu gazetedeki tecavüz haberleri de 2009, 2011 ve 2015 olmak üzere üç farklı yılı kapsayacak şekilde taranmıştır. Bu yılların tercih edilme sebebi bu üç yılda da tecavüz ve cinayetle sonuçlanan Münevver Karabulut, Sema Karakoca ve Özgecan Arslan vakalarının olmasıdır. Bu durum ilgili yıllarda tecavüz haberlerinin kamuoyu gündeminde sıkça yer bulmasina neden olmuştur.

\section{Karikatürlerde Tecavüz, Toplumsal Cinsiyet ve Mekân}

\subsection{Mekân ve Zaman}

\subsubsection{Mekân: "Şeytana Uyar Sokak"}

İncelenen tecavüz içerikli karikatürlerde kullanılan mekânların \%47'sini ormanlık alanlar, \%26'sını yoksul mahalleler, \%20'sını apartmanların arasındaki park ve bahçeler ve \%7'sini otobüs mekânları oluşturmaktadır. Bu haliyle karikatür tecavüzün salt kamusal alanlarda gerçekleştiği alt metin olarak sunulmaktadır. Bunlar içinde ilk olarak ormanlık alanlar, yoksul mahalleler ve park ve bahçelere bakıldığında, doğayla ilişkili bir göndermenin olduğu açıkça görülmektedir. Kent içindeki kurtarılmış bölgeler olan bu alanlar, doğa ve kurgu arasında kalmayı ifade etmektedirler. Tecavüz alanı olarak sunulan bu mekânlarda yaban olan, doğanın içerisindedir ve üzerine düşen görevi yapıyordur. Acıkmıştır ve avlanıyordur. Bu kurgu içinde yoksul mahalleler de yer bulmaktadır. Kentlerdeki yoksul mahalleler ve onların sakinleri, çoğunlukla kente (medeniyete) adapte olamamaları ve kırdan (doğaya en yakın yerleşmelerden) göç etmeleri bakımından araştırılmışlardır. Zaten bunu sağlama iddiası taşıyan kentsel dönüşüm bu yoksul mahallelerden hiç eksik olmaz. Bu haliyle tecavüz 
mekânı olarak yoksul mahallelerin kullanılması doğaya ve yabana karşılık gelmektedir; avlanma alanlarıdır ve ehlileştirilmesi gereken bir mekân olarak sunulmaktadırlar. Karikatürlerdeki bir diğer tecavüz mekânı otobüslerin içleridir. Bilindiği gibi otobüsler şehirlerin sokaklarında dolaşır; yolcular (av) ona biner ve inerler. Otobüsün sabit bir güzergâhı olsa da sabit bir mekânı yoktur ve sürekli hareket halindedir. Bu hareketliliğin kendisi karikatür üzerinden yine doğaya/göçebeliğe gönderme yapmaktadır. Sonuçta, karikatürlerin mekân kurgusunun doğaya göndermede bulunuyor oluşu tecavüz olgusunun kanıksanmasına ve doğallaştırılmasına sebep olmaktadır.

Karikatürlerde tecavüzün mekânlarına dikkatle bakmak, bazı toplumsal okumalara imkân vermektedir. Aşağıdaki karikatürde (Şekil 1) sokak kırmızı fon üzerinde 'Şeytana Uyar Sokak' ${ }^{6}$ olarak adlandırılmıştır. Aslında Türkiye'de Sokak tabelaları çoğunlukla mavidir. Ancak buradaki kırmızı renktedir. Kırmızı renk tehlikeyi, alarm durumunu, merakı, arzuyu ve pornografiyi temsil etmektedir. Bu mekândaki uyarıcılar eşliğinde tecavüz eylemini gerçekleştiren fail 'şeytana uymuş' oluyorsa, aslında eylemin sorumluluğunu yansıtarak kendinden uzaklaştırmaktadır. Ayrıca karikatürdeki binanın duvarlarının sıvası dökülmüştür. Çöpler sokağa gelişi güzel bırakılmıştır. Bu karikatürde çöplerin yerde olması ve bakımsızlık kamu hizmetinin uğramadığı ve alt yapı hizmetlerinin iyi olmadığına işaret etmektedir. Bu haliyle karikatürdeki bu tasvir yoksul bir mahalleye işaret etmektedir. Tersinden bir okuma yapıldığında, kamu hizmetlerinin düzenli yapıldığı ve bakımlı durumdaki mekânlarda tecavüz ihtimalinin azaldığı veyahut olmadığı çıkarımı da yapılabilir. Karikatürdeki kurgudan yola çıkarak, yoksul olmak ile tecavüzcü olmak arasında görsel bir korelasyon kurulduğu görülmektedir. Yoksul olmak ile suçlu olmak ilişkilendirilerek mekân ötekileştirilmektedir.

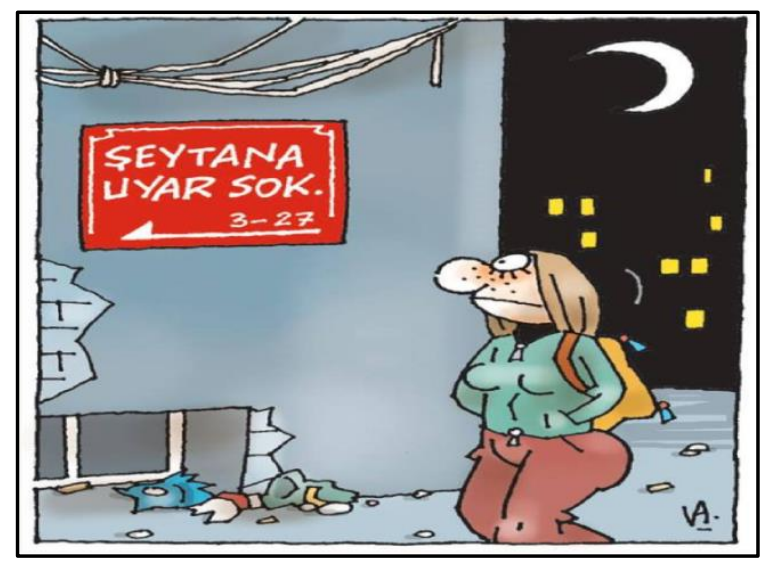

Şekil 1. Karikatürlerde Kullanılan Mekân ${ }^{7}$

Aslında yoksul mahalleler ve suç ilişkisi farklı çalışmalara da konu olmuştur. Hatta mala, cana veya kişiye karşı işlenen suça ilişkin çalışmalarda ön plana çıkan yoksul mahalleler "sıcak mekânlar" (suç merkezleri) olarak kavramsallaştırılmaktadır. Yapılan çalışmalarda bu mahallelerde de suçlular ikamet etmektedirler ama suçu işledikleri mahalleler farklıdır (Uğur, 2013; Uzun ve Aliağaoğlu, 2009; Üresinler, 2005). Yoksul mahallelerin suçla ilişkilendirilmesini sorgulayan araştırmacılar, suçun arkasında yatan yapısal, siyasi, toplumsal ve sömürü ilişkilerine vurgu yapmaktadırlar (Wikstrom, 1995; Shoham ve Hoffmann, 1991; Shoham ve Hoffmann, 1991; Park ve Burgess, 2012; Becker, 
2015; Stavrides, 2016). Bazı bölgeler ekonomik olarak alt sınıf veya kültürel olarak alt kültür olmayabilir fakat bilinçli olarak prestij açısından düşük olarak sınıflandırılmaktadır. Bu ilişkiler ortaya konmadan mekânın bu şekilde sınıflandırılması, yapısal düzeyde statü grupları üretmektedir. Zira yerleşim bölgelerine bu şekilde atfedilen homojenlik genelde gerçeklikten ziyade efsanedir (Hurst vd., 2016).

Mekânların bu şekilde sınıflandırılmasını Goffman (2018:123) mekâna takılan etiket kavramı üzerinden değerlendirmektedir. Mekânların etiketlenmesi, onları vitrin bölgesine dönüştürmektedir. Mekâna vurulan etiket o eylemin artık orası dışında yapılamayacağını açığa vurmaktadır. Goffman bunu anlatırken soyunma odası örneğini vermektedir. Mesela "soyunma odası" tabelası bir odanın kapısına asıldığında insanlar o oda içerisinde soyunacaklardır. Bu etiketleme belli davranış biçimlerinin orada yoğunlaşmasına sebep olmaktadır. Aslında herhangi bir oda soyunma için işlevsel olmasına rağmen, etiket bunu engellemektedir. $\mathrm{Bu}$ yolla etiketleme, bir iktidar yaratmaktadır ve egemen kimliğin müstakil alanına dönüşmektedir. Bu durum egemen kimliğe yönelik itiraz ve eleştirilerin dillendirilebileceği kanalların ortadan kalkması anlamına gelmektedir (Küçük ve Türkmen, 2017: 185). İtiraz ve eleştirilerin ortadan kalmasının yanı sıra üretilen kategoriler ve mekânsal ayrımlar, bazı hayat tarzı farklılıklarını yaratmaktadır. Aynı zamanda, bazı hayat tarzı farklılıkları, kategorileri ve mekânları üretmektedir. Bu yolla belli mekânlar üzerinden geliştirilen kurgular, hayaller, fanteziler ve stereotipler hayat tarzı farkl1l1klarının marjinalleşmesine sebep olmaktadır. Dolayısıyla mekâna iliştirilen etiketler hem mekânın kendisini hem de hayat tarzını tektipleştirerek "farkçı ırkçıllğgl" üretmektedir (Balibar ve Wallerstein, 2017: 32). Bu bağlamda karikatürlerdeki mekânlar etiketlenmekte ve suçla ilişkili olarak marjinalleştirilmektedirler. $\mathrm{Bu}$ mekânlarda bulunan insanlar ise bu marjinalleştirilme gerçeğini kabul ettikleri varsayımıyla, orada bulunmaları bakımından suçlanmaktadırlar. Bu bir bakıma, orada maruz kaldıkları cinsel şiddet konusunda mağdurların sorumlu tutulması demektir.

\subsubsection{Zaman: "Ne güzel bir gece değil mi?"}

Tecavüz içerikli karikatürlerde tasvir edilen zamanın \%83'ünü gece, \%10'unu belirsiz zaman ve \% 7'sini gündüz oluşturmaktadır. Aşağıdaki örnek karikatürde de görüldüğü gibi (Şekil 2), geceyi yıldızlar ve ay temsil etmektedir. Zaman vurgusunu güçlendirmek için de 'ne güzel gece değil mi? İfadesi kullanılarak okuyucunun, olayın zamanla ilişkisini kavraması sağlanmaktadır. Zaman tam olarak gecenin ortasıdır. Ne güneş batmak üzeredir ne de günün aydınlanmasına ramak kalmıştır. $\mathrm{Bu}$ zamanlama, faile tecavüz eylemini tekrarlayabileceği, mağduru tehdit edebileceği ve/veya öldürüp terk edebileceği veya onu gömebileceği zamanı vermektedir. Bu durum aslında erkeğin zamanının sınırsızlığını da göstermektedir. Gündüz zaten zamanın sahibi olan erkek, gecenin de sahibi olarak sunulmaktadır. Zamanın kontrolünü eline alan ataerkil erkek günün her saatinde istediği yerde 'hazır ve nazır'dır'. Zamanın iktidarı ve yönetimi bu anlamda karikatürlerde de tersyüz edilmemiştir. Öte yandan kadınların zamanları, mekânların da olduğu gibi, sınırlandırılmıştır. Onların günün hangi saatinde, nerede ve nasıl olacakları ataerkil gelenek tarafindan belirlenmektedir. Buna karşıllı heteroseksüel erkeklerin dışında gece dışarıda olanlar öteki olmak (seks işçisi, 'hafif kadın' vb.) ile ilişkilendirdiğinden gecenin ontolojisi sembolik olarak bir etikete dönüşmektedir ve gece dişarıda olan 
‘ötekiler’ o etiketlemeye maruz kalmaktadır. Bu bakışa göre gece dışarı çıkan bir kadın olası bütün ihtimalleri göze almış demektir.

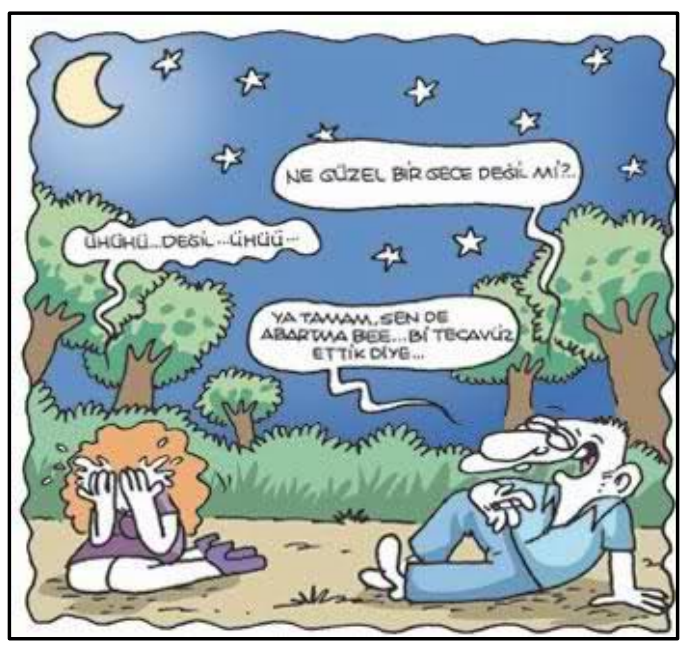

Şekil 2. Tecavüz zamanına iliş̧in örnek

Tecavüzle ilişkili karikatürlerde kullanılan zamanın çok az bir kısmı gündüze işaret etmektedir. Fakat bu karikatürler gündüz tecavüz vakasının gerçekleştiğine ilişkin karikatürler değildir. $\mathrm{Bu}$ karikatürler tecavüz olayının sonrasında yakalanan failin, otoritenin ve hak arama mekanizmalarının temsilcisi durumundaki hâkim veya polis ile karşılıklı konuşmalarını içermektedir. Burada otoritenin tecavüzün gerçekleştiği zamanda orada temsil edilmemesi oldukça ilginçtir. Ayrıca hiçbir karikatürde otorite, tecavüzü engellerken görülmemektedir. Dolayısıyla gece, otoritenin görünür olmadığı bir zamandır. Bu durum, geceye ve gündüze atfedilen toplumsal değerle de ilgilidir. Gece ve gündüz arasındaki zıtlık iyi ve kötü arasındaki zıtlık gibi değildir. Gündüz ışığın varlığına, gece ise 1şığın yokluğuna işaret etmektedir. Varlık olan 1şı̆̆ın yokluğu, gece olarak karşımıza çıkar. Zamanı gece ve gündüz olarak bölen ışığın kendisidir ve aslında daha genel olarak zamanı bölen ve ona zitlıklar $^{10}$ üzerinden anlamlar yükleyen toplumdur. Geceye ve gündüze atfedilen bu toplumsal değerler geceyi ve gündüzü farklı boyutlarda anlam dünyamıza yükleyerek zamanın cinsiyetlendirilmesine neden olmaktadır. Zamanın cinsiyetlendirilmesi, mekânı zamansal olarak parçalamaktadır. $\mathrm{Bu}$ bölümlemede gece sürekli olarak kötülenmiştir ve belirsizlikleri, karanlık ruhları içerisinde barındırmaktadır. "Gecenin şerri” vardır ve bu şerden sı̆̆ınılması gerekmektedir. Bu kurgu içinde gecenin şerrinden sığınılması gereken güvenli mekân ise evdir. Dolayısıyla gece, kadınlar için bir tecrit zamanıdır ve onlar, bir erkeğin korumasıyla dışarı çıkabilmektedirler ${ }^{11}$.

Zamanın cinsiyetlendirilmesi ile parçalanan mekân üzerine Andrea Dworkin (2015) 'Geceyi geri al' (take back the night) yürüyüşünde yaptığı konuşmada önemli eleştiriler getirmektedir: 'Gece, kadınlara tehlike vaat eder. Bir kadın için gece sokakta yürümek yalnızca taciz edilme riski altında olmak değildir, aynı zamanda - erkek egemen anlayışa göre- taciz edilmeyi istemek, "aranmak" anlamına gelir. Gecenin hudutlarını aşan kadın, uygar davranışın temel kuralını bozan bir kanun kaçağıdır: iffetli bir kadın gece dışarı çıkmaz, hele de yalnız başına ya da sadece diğer kadınlarla birlikte... Tecavüzcüler gece yasalarını uygulama hakkına sahiptir: kadını sinsice izlemek ve onu 
cezalandırmak... ${ }^{12}$. Bunlardan yola çıkarak tecavüz karikatürlerindeki zamanın, mekânlarda olduğu gibi geleneksel ataerkil yapının düşünsel arka-planını görünür kıldığı, bu zamanın dışındaki tecavüzleri dikkate almadığı söylenebilir. Ayrıca bu karikatürlerin, gece kadınları tecavüzden koruyabilecek mekanizmaların yoksunluğuna ilişkin bir eleştiri barındırmadığı söylenebilir. En belirgin eleştiri, gündüz faillerin aynı otoritelerce yargılanmaları esnasında korunması üzerinedir.

\subsubsection{Kadın ve Erkek Tiplemeleri: 'O mini eteği giymesinden belliydi'}

Karikatürlerde üretilen kadın erkek tiplemelerinin karikatüristin görüşlerinin ürünü olup olmadığı ve okuyucuyu eleştirel farkındalık sürecine sokmaya yönelik bir kaygı taşıyıp taşımadığı belirsizdir. Bu nedenle ortaya çıkan ürünü ele alış biçimi, onun sosyal bağlamla ilişkisi üzerinden okunabilir. Bu çalışmada da karikatüristin bakışı değil, temsilin anlamına odaklanılmaktadır. Bu bağlamda kaleme alınan bu makale kapsamında incelenen 30 tecavüz içerikli karikatürde yer alan mağdur ve failler, belirli ortak özelliklere sahip olma üzerinden temsil edilmektedirler. Buna göre, karikatürlerin \%78'inde erkekler esmer, göbekli, kalın ve birleşik kaşl1, kıllı ve uzun burunlu resmedilmişlerdir. Ayrıca bunların içinde bazı erkek tiplemeleri \%22 oranında kaslı ve koca dişli olarak resmedilmiştir. Tecavüz içerikli otuz karikatürde kadın temsillerinin \%83'ü aşırı makyajlı, beyaz tenli, büyük memeli ve geniş kalçalı, mini şort/etek giymiş olan ve açık veya renkli saçlı olarak tiplendirilmiştir (Şekil 3). Özellikle sarı saç renginin yaygın olması, 'aptal sarışın' tiplendirmesiyle ilgilidir ve bu kadınlar üzerinde kolayca kuvvet kullanılabileceğine ilişkin bir gönderme içermektedir. Buna ek olarak karikatürlerin \%17'sinde kadınlar yüksek topuklu ayakkabılar giymektedirler. Bu tiplemelerle karikatürler bir alg1 üreterek bu tipteki kişilerin tecavüzcü olduğunu düşündürttüğü gibi bu tiplemelerin dışındaki tecavüzcülerin gözden kaçmasına ve daha rahat hareket etmelerine sebep olmaktadır. Nasıl ki tesettür gizlenen dişiliğin bir simgesiyse sakal, kıl ve erkekteki çıplaklık da açığa vurulan erkekliği simgelemektedir. Karikatürde yer almayan tesettür ise gizlenmeyen dişilik anlamına gelmektedir. Tiplemelerin çıplaklık üzerinden inşa edilmesini anlamlandırmak her ne kadar kültürel mitler ile uyumlu olsa da bu durumu daha iyi anlamak için aslında örtünmeye atfedilen toplumsal değere bakmak gerekir. Mesela Asur Yasalarına göre 'beylerin' karılarının ve kızlarının peçelenmesi zorunluydu. Buna karşılık fahişelerin ve kölelerin peçe takması yasaktı (Berktay, 2016: 83). Lerner peçe yalnızca yüksek sınıflara özgü bir simge olarak kalmayıp daha önemlisi herkesin (bütün erkeklerin) kullanımına açık olan kadınlar ile yalnızca tek bir erkeğin kullanımına açık ve onun 'koruması' altında olan 'saygın' kadınların birbirlerinden ayırmaya olanak verdiğini belirtmektedir (1986: 83’ten aktaran Berktay, 2016). Dolayısıyla kadının iffeti maruz kalacağı tecavüzden uzak oluşu nispetindedir; bu uzak kalma için örtünmeden daha güvenli bir yolun olmadığı ön plana çıkarılmaktadır (Göle, 2016: 76-77). 


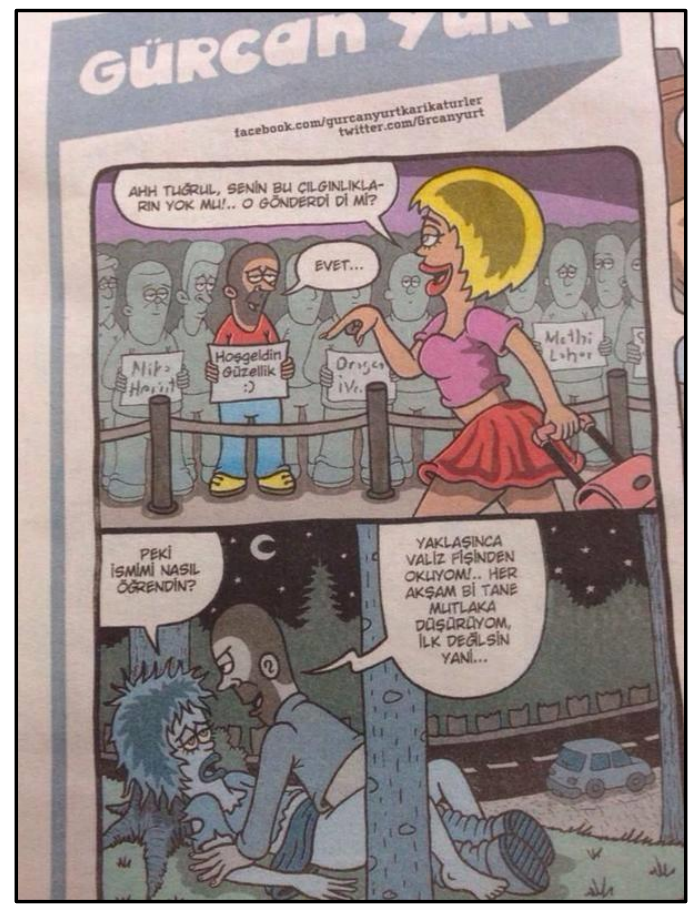

Şekil 3. Tecavüze ve temsile ilişkin bir karikatür ${ }^{13}$

Karikatürlerde tecavüz faili olarak gösterilen erkekler, kadınlardan yaşça büyük olarak temsil edilirken; kadınlar, daha genç olarak çizilmişlerdir. Bu da gençlik ve tecavüz mağduru olma arasında bir ilişki kurulduğu ve daha yaşlı olanların daha az tecavüz riski altında bulunduğu fikrini yansıtmaktadır. Ayrıca bu genç kadınların karikatürlerde ne iş yaptığı ve ne için orada bulunduğuna ilişkin herhangi bir gösterge yoktur. Onlar, hep geçip giden, yolculuk halinde olan ve bu yolculuğun yönünün belirsizliğine razı olarak temsil edilirler. Bir başka deyişle, sokak bir tehlike mekânıdır ve tecavüzün gerçekleştiği yerdeki kadın, sadece o sokaktaki kadın olarak buna maruz kalır. Dolayısıyla temsildeki kadına saldırı, aslında onun sokakta var olma biçimine yöneliktir. Kadınların bir yerde çalışan veya işveren durumundayken tecavüze uğradıklarının örneğinin olmaması da bununla ilgilidir. Zaten karikatürlerde kadınların erkeklere oranla daha az lider rollerine sahip oldukları bilinmektedir (Streicher, 1974: 125-129). Yine bir yere gitmek için sokakta bulunan kadınlar, oldukça uysal, duygusal, arkadaş canlısı ve kırılgan bir şekilde temsil edilirler ve bu temsilin karikatürlerin genelinde söz konusu olduğu Thompson ve Zerbinos (1995: 668) tarafından da ortaya konmuştur. Erkekler ise kadınlara göre daha saldırgan ve sinirlidirler (Oliver ve Stephen 2001: 68). Bu özellikleri taşıyan erkeklerin akıl ve iradesi dışında tecavüzü gerçekleştirdiklerine gönderme yapan çizimler de mevcuttur. Erkeğin, tecavüz mağduru kadın tiplemelerinden biriyle karşılaşması halinde cinsel olarak uyarılması buna örnektir (Şekil 4). Bu durum erkeğin tecavüzden sorumlu olmadığını, bunu yaratanın tiplemedeki kadın olduğu gösterilmektedir. Zaten kültürel olarak Yusuf Suresi'nde baştan çıkarıcı kadın ve onu dizginleyen erkek mitleri de (İlkaracan, 2015: 18) ) $^{14}$ bu durumla uyumludur. Karikatürlerdeki kadın tiplemesine uymayan kadın ise, baştan çıkarıcı görülmemekte ve tecavüzün hedefi olarak gösterilmemektedir. Hatta erkeği, tecavüz mağduru olma potansiyeli taşıyan kadından 
'korumaktadır'. Son olarak, mağdurların faillerle yakınlık ilişkisine bakıldığında, onların neredeyse ilk kez karşılaşan, birbirlerini daha önce tanımayan kişiler olarak temsil edildikleri görülmektedir. Dolayısıyla tecavüzün yönünün, yabancı olana doğru olduğu ön plana çıkmaktadır.

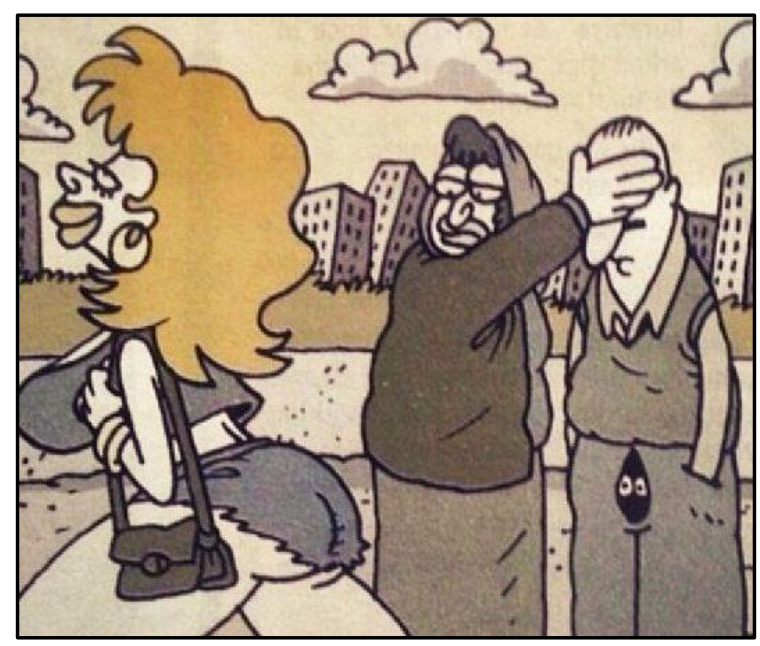

Şekil 4. Tecavüze ve temsile ilişkin bir karikatür ${ }^{15}$

$\mathrm{Bu}$ temsillerin politik bir yanının olduğu şüphesizdir (Bobo, 1992: 66). Çünkü karikatürdeki bir yüz herhangi bir yüz değildir ve anlam dünyası inşa eder (Ross, 1974: 285). Karikatürist herhangi bir bireye bakarak bunu çizmez, çizimden önce tiplemeyi zihninde soyut olarak üretir ve sonrasında somut olarak ifade eder. Buna göre tecavüze ilişkin üretilen temsillerin gerçekte karşıllı̆̆ vardır fakat çok az bir kısmını temsil etmektedir ${ }^{16}$. Buna rağmen eksik temsil yaratılmasının altında yatan nedir? Bunun cevabı temsilin rolünde gizlidir. Aslında temsiller anlatımın sürdürülmesini sağlarlar (Smith, 1996: 33). Örneğin; köylü tiplemeleri yüzlerce çeşit olmasına rağmen temsil ile tek tipe indirgenmektedir (Dutton, 2013: 158-160). Böylece tek bir tip ele alınarak ulusal ve evrensel hatalı tanımlamalar ortaya çıkmaktadır. Bir kişiyi basmakalıp şekilde karikatürize etmek, onu bulunduğu toplumun çarpık bir metası haline getirir ve sömürür (Banks vd., 1993: 296). Ayrıca bir grup insanın temsil edilme şekli, bu insanlara sosyal ve politik olarak nasıl muamele edildiklerinde belirleyici bir rol oynayabilir. Aslında resmettikleri doğru değil, bir keşif ve ifşa ile bir icattır (Dutton, 2013: 163). Temsillerin kültür olarak inşa edilmesi coğrafi bölgelere karşı üretilen etnik varsayımları kolaylaştırmaktadır. Bir sosyal grup belli özelliklerle tanımlandığında (dil, coğrafi köken, gelenek, etnisite ve politik kimlik) bu özellikleri içeren tüm olumsuz tanımlamalar bu kimliklerin üzerine yapışıp kalmaktadır ${ }^{17}$. Zaten karikatürlerdeki yazılarda faillerin şive ifadeleri, temsil edilen olgu ile sosyal tabaka arasında bağ kurmaktadır. Dolayısıyla her temsil, kurguyla gerçeklik arasında filizlenir ama gerçekliği yansıtıcı işlevi görmeyebilir. Gerçeklik, söylemin ortaya çıkmasına neden olur, ancak söylem, kadınların günlük yaşamındaki gerçekliğin sadece bir kısmını ifade eder. Karikatürler gerçekliğin bir bölümünü ortaya çıkarırlar ve bütünü oluşturan gerçekliğin büyük çoğunluğunu dışlarlar (Al-Mahadin, 2003: 132-135). Ayrıca temsillerin örtüşmesi, damgalamaya da neden olabilir. Bunu ortaya koymak için konusu tecavüzden farklı olan karikatürler incelenmiştir. Erkek tiplemelerinin şehre uyumla veya belirli meslek gruplarıyla ilgili karikatürlerdeki erkek tiplemeleriyle uyuştuğu (Şekil 5) ${ }^{18}$; kadın temsilleriyle de şehirli kadın tiplemeleriyle örtüştüğü görülmüsstür (Şekil 6). 
Dolayısıyla karikatürler ötekini inşa etmekte ve onun parçası olan köylüyü alt kültür olarak sunmaktadırlar. Bu yolla kentsel orta sınıf normatif olarak doğrulanmakta ve arzu edilerek arzunun nesnesi haline gelmektedir (Williamson, 1995: 19'dan aktaran Banks vd., 1993). Bir başka deyişle tecavüz içerikli karikatürlerde alt sınıf üst sınıfa tecavüz etmektedir. Esmer ya da siyah erkek beyaz kadına tecavüz ettirilmektedir. Bir taraf şehirli, zengin, orta sınıf diğer taraf öteki, göçmen ve köylüdür. Bir yandan bir taraf yokluğu ifade ederken diğer taraf varlığı ifade etmektedir. Yokluğu temsil eden kişi, yokluğunun sebebi olarak varlıklıyı görür ve ondaki ona ait olanı almak için ona saldırır. Hiç bir zaman bir araya gelemeyecek veya gelmek istediklerinde bir yı̆̆ın engellerle karşılaşılması zorla ele geçirmeyi üretmiştir. Bu durumda aslında onun bedenine saldırarak bir yaşam tarzından veya kendini sömürdüğünü düşündügü şeyden intikamını almaktadır. Böylece cinsellik bir iktidar aracı olarak simgeleşmektedir (Donnan ve Wilson, 2002: 251-256).

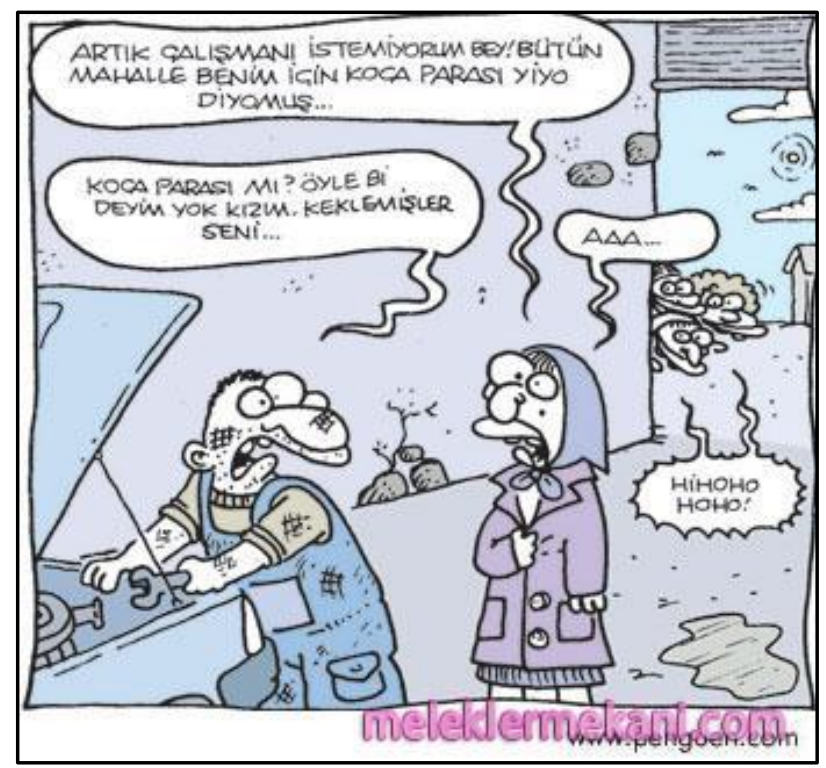

Şekil 5. Araç tamircisine ilişkin tipleme ${ }^{19}$

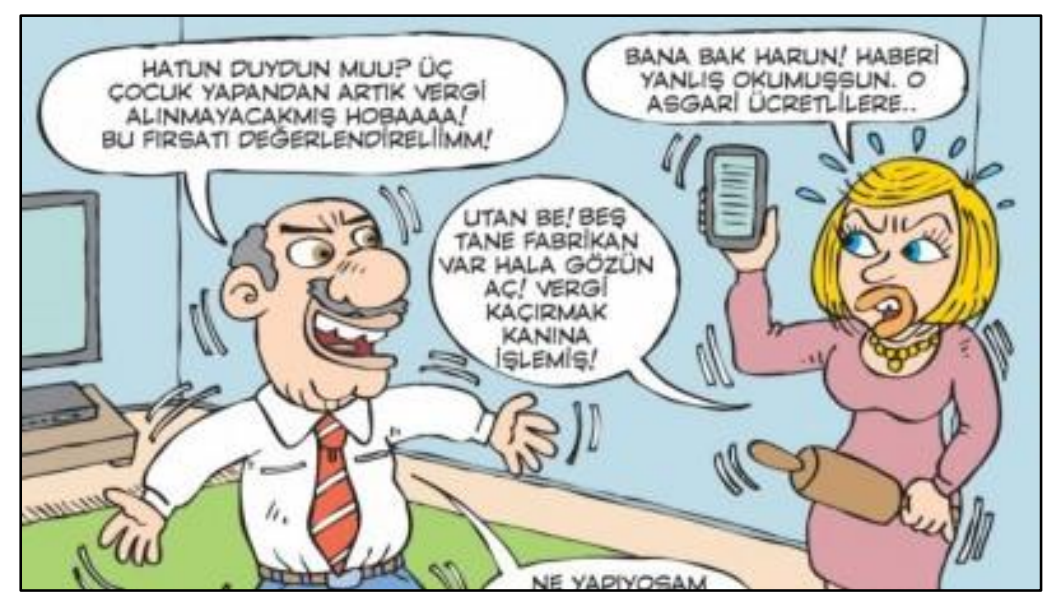

Şekil 6. Ekonomik sınıfı ifade eden karikatür ${ }^{20}$ 


\section{Gerçeğin Dışavurumu: Tecavüz haberlerinde failler, mağdurlar ve mekânlar}

Tecavüz içerikli haberlerde mağdurların \%21'ini öğrenciler, \%29'unu çocuklar, \%11'ini kafe çalışanları, \%8'ini engelli bireyler ve \%8'ini de işçiler oluşturmaktadır. Haber temsillerindeki mağdurlar karikatüre kıyasla oldukça çeşitlilik göstermektedir. Mağdurların tamamı ise şöyledir: Öğrenci, çocuk, kafe çalışanı, engelli birey, işçi, muhasebeci, sekreter, hasta, çırak, güzellik uzmanı, ev hanımı, hemşire, müşteri, solist, yaşlı kadın ve fotomodel ${ }^{21}$. Faillerin ise $\% 11$ 'ini öğretmenler, \%9'unu şoförler, \%7'sini akademisyenler, \%7'sini işçiler, \%7'sini imamlar \%5'ini iş adamları, \%5'ini öğrenciler ve \%5'ini polisler oluşturmaktadır. Faillerin tamamı ise şöyledir: Öğretmen, şoför, akademisyen, işçi, imam, işadamı, öğrenci, polis, doktor, esnaf, kafe işletmecisi, memur, mühendis, siyasi parti başkanı, patron, avukat, cerrah, uzman çavuş, yönetici, çiftçi, güvenlik görevlisi, korucu, muhtar, müteahhit, bilgisayarcı, emekli, gazeteci, kurye, muhasebeci, radyocu, sağlık personeli, teğmen, temizlikçi, tornacıdır. Aynı haberlerde mağdurların çeşitliliğinin faillerin çeşitliliğinden daha az olduğu gözlemlenmektedir. Mağdurların ve faillerin fiziksel özelliklerinde ise büyük bir çeşitlilik söz konusudur.

Tecavüz içerikli haberlerdeki mekânlara bakıldığında ise toplam 28 farklı mekân öne çıkmaktadır. Bu mekânların \%29'u failin evine, \%11'i mağdurun evine karşılık gelmektedir. 28 farklı mekânı toplulaştırıldığında ortaya şöyle bir görünüm çıkmaktadır: Faile ait mekânlar (ev-dükkânaraç) \%59, mağdura ait mekânlar (ev-dükkân) \%12 ve kamusal mekânlar (park ve bahçe-ormanlık alan-mezarlık) \%29 oranında temsil edilmektedir. Buradan hareketle fail ve mağdura ait mekânlar toplam mekânın \%71'ini oluştururken kamusal mekân \%29'unu oluşturmaktadır. Başka bir değişle tecavüzlerin \%71'i özel alanda meydana gelmektedir. Karikatürlerde zaman ise oldukça farklı şekillerde ifade edilmiştir. Bu nedenle haberlerde yer alan, 'akşamüstü', 'gece saatleri', 'gündüz vakti', 'iş çıkışı', 'kahvaltıdan sonra' ve 'saat' ile belirtilen ifadeler gece ve gündüz olarak kavramsallaştırılmıştır. Buna göre incelenen haberlerdeki tecavüzlerin $\% 45$ 'inin gece ve $\% 55$ 'inin gündüz meydana geldiği görülmüştür.

Bunların yanı sıra bir diğer önemli unsur, mağdur ve failin yakınlık durumudur. Gazete haberlerinden elde edilen verilere göre, mağdur ve fail arasındaki yakınlık ilişkisi 26 farklı kategori yaratmaktadır. Fakat bu kategoriler birleştirilerek beş kategoriye indirgenmiştir. Bu beş kategoriye göre Çekirdek Aile (Anne-Baba-Çocuk-Ăgabey-Abla) \%5, Geniş Aile (Dede-Dayl-Teyze-KuzenNişanlı-Amca-Gelin-Enişte) \% 10, Uzak Çevre (Mahalle-Komşu-Tanıdık) \%43, Sosyal Çevre (İş-OkulArkadaş-İlişkili Diğer Yapılar) \%28 ve Hiç Tanımadı̆̆ı Kişi \%13 olarak tespit edilmiştir. Yukarıdaki kategoriler iki kategoriye indirgendiğinde; Tanıdık (Çekirdek Aile-Geniş Aile- Sosyal Çevre) \%87 ve

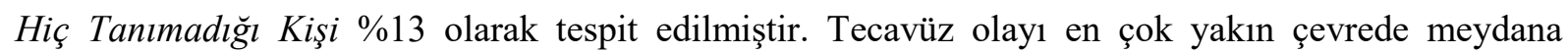
gelmekte ve kamusala çıkıldıkça bu oran azalmaktadır. Ayrıca karikatürlerden farklı olarak haberlerde, kadınların medeni durumu ve çocuk sahipliği bilgisine yer verilmektedir. Çünkü bunlarla kazanılan statünün toplumsal anlamı, bekâr olmaktan farklıdır. Yine bu haberlerde mağdurla fail arasında bir hiyerarşinin olduğu göze çarpmaktadır. Bu hiyerarşi yaş ile de kurulmakla birlikte çoğunlukla statü ve sınıf üzerinden kurulmaktadır. Buna, patron-sekreter ve öğretmen-öğrenci örnek verilebilir. Bu statüde mağdurların sessiz, öksüz, engelli, ihtiyaç sahibi olarak tanımlanmaları yaygındır. Ayrıca failler, karikatürlerde temsil edildiği şekilde, mağdurlardan yaşça büyüktürler. 


\section{Sonuç}

Tecavüz karikatürlerindeki temsiller ve bunun gerçeklikle ilişkisi üzerine yapılan bu çalışmada, faillere yönelik oluşturulan erkek tiplerinin gerçek haberlerle birebir uyuşmadı̆̆ görülmüştür. Buna göre karikatürlerde fail olarak temsil edilen alt sınıftan farklı olarak, haberlerde orta ve üst sınıftan çok sayıda faille karşılaşılmıştır. Aynı durum mağdurlar için de geçerlidir. Zira karikatürlerde mağdur olarak kentli orta ve üst sınıf kadın ön plana çıkarken, haberlerde alt sınıftan pek çok kadının da tecavüze uğradığı görülmüştür. Hatta kırılganlığın artışıyla tecavüze uğrama ihtimalinin arttı̆̆ 1 , engelli ve çocuk tecavüzlerinde açıkça anlaşılmaktadır. Ayrıca karikatürlerde failler ve mağdurların belirli mesleklerle ilişkilendirildikleri görülürken, gerçek hikâyelerin yansıması olan haberlerde daha çeşitli meslek gruplarından fail ve mağdurlara rastlanmaktadır. Bu durum, yapılan tektipleştirmenin gerçek hayattaki karşılığının zayıf olduğu göstermektedir.

Çalışmanın bir diğer bulgusu, karikatürlerdeki zaman vurgusunun haberlerdeki zamandan farklılaşmasıdır. Karikatürlerde tecavüz zamanı olarak geceye atıf varken, tecavüz haberlerinde gündüz gerçekleşen tecavüzler oldukça fazladır. Bunun yanında karikatürlerde kamusal mekânda yoğunlaşan tecavüz temsilleri, haberlerde doğrulanmamaktadır. Zira taranan haberlerde tecavüzlerin sıklıkla güvenlikle kutsanan özel alanda gerçekleştiği anlaşılmıştır. Ayrıca özel alanda karşılaşılan fail ve mağdur arasındaki yakınlık ilişkisi, karikatürlerdekinin tam tersinedir. Zira karikatürlerde yabancılar arasında gerçekleştiği sunulan tecavüzler, haberlerde sıklıkla yakınlık ilişkisine sahip kişiler arasında meydana gelmektedir. Bütün bu nedenlerle, tecavüzü belirli tiplerin belirli zamanda, belirli mekânlarda var oluşla ilişkilendiren karikatürler, gerçek hayatta meydana gelen tecavüzlerin taraflarını, mekânlarını ve zamanlarını açığa çıkarmaya hizmet etmemektedirler.

\section{Notlar}

\section{04.05.2019 tarihinde}

http://tdk.gov.tr/index.php?option=com_bts\&arama=kelime\&guid=TDK.GTS.593f8669c00356.28508220 adresinden alınmıştır.

2. Dergi veya internet adreslerinin çizgisi ya da toplumsal olarak bulundukları konumlar dikkate alınmamıştır. Çünkü tecavüz bu dergi veya internet adreslerinden bağlam olarak daha üst bir olgudur ve söz konusu kaynakların konuyu inşa ediş biçimleri başka bir araştırma konusudur.

3. Ayrıca kadın tecavüze günün geç saatlerinde maruz kalmışsa, ona yüklenen sorumluluk da artmaktadır (Bolt ve Caswell, 1981).

4. Bununla ilişkili olarak açık alan korkusunun daha çok kadınların yaşadığı bir deneyim olması durumunu Alkan "kadınlara verilen tarihsel gözdağı" olarak yorumlamaktadır (2005).

5. Tensiye, 22: 23-24

6. Tecavüz ile ilgili davalarda failler bazen, 'pişmanım', 'şeytana uydum' diyebilmektedir.

7. 04.02.2019 tarihinde https://twitter.com/search?q=tecav\%C3\%BCz\%20karikat\%C3\%BCr\&src=typd\&lang=tr adresinden alınmıştır.

8. Foucault'un (2016) ‘'̇ktidar, her yerde hazır ve nazırdır’ ifadesine atfen kullanıyoruz.

9.04.02.2019 tarihinde https://www.uludagsozluk.com/k/tecav\%C3\%BCz-sonras\%C4\%B1-ya\%C5\%9Fanan-diyaloglar/ adresinden alınmıştır.

10. Kutsal kitaplarda gece ve gündüz kavramlarının kullanımı zıtlıklar veya olumsuz çağrışımlar üzerine kurgulanmaktadır. Örneğin gece ve gündüz ile birlikte belirli zıtlıklar içerisinde kullanılan ve geceye gönderme yapıldığı durumlar şöyledir: 
gizli-açık, diri-ölü, hoşlarına gitmeyen şeyleri gece yaparlar, suçlu-günahkâr, yaşatan-öldüren, gece sizin için bir elbisedir, geceyi bir örtü yaptık (Altuntaş 2007, Kuranı Kerim Meali ), gece yürüyen sendeler, gece saldırd1, bu gece benimsin, o gece onunla yattı, fahişenin evine gece girdi, gece pusuya yat, gece seni öldürmeye gelecekler, hırsız gibi geceleyin sıvış, gecenin dehşetinden korkma, gecenin tehlikelerine karşı kendini savun, bu hece horoz ötmeden beni inkâr edeceksin, o gece şarap içip babasıyla yattı (Kitabı Mukaddes, 1988).

11. Farklı coğrafyalarda karşılık bulan bu durum, Türkiye'de de toplumsal kabule erişmiştir. Türkiye toplumunda bir kadının gece geç saatte tek başına sokağa çıkmasının hoş karşılanmaması (Yücel, 2018: 103) bununla ilgilidir.

12. 04.02.2019 tarihinde http://www.5harfliler.com/gece-ve-tehlike-andrea-dworkin/ adresinden alınmıştır.

13. 04.02.2019 tarihinde http://www.5harfliler.com/penguende-tecavuz-ppp/ adresinden alınmıştır.

14. Batı toplumlarında bu konudaki karikatürlerde kadın ve erkek tiplemeleri oryantalist bakış açısıyla ve etnisite etrafında kurgulanmaktadır. Müslümanların Batı Dünyasına göç etmesiyle birlikte örtü üzerinden karikatürize edilmeleri yaygınlaşmıştır.

15. 03.02.2019 tarihinde http://www.karikaturing.com/2013/11/goz-kaymas.html\#.XHo8oogzbIU adresinden alınmıştır.

16. Köleler genelde pamuk tarlalarında çalışıyor olarak tasvir edilirler fakat gerçekte birçoğu endüstri alanlarında çalışmışlardır (Pilgrim, 2000). Karikatürdeki temsil durumu da bunun gibidir.

17. Mesela, görsel ve yazılı üretimin Appalaş'lardaki yerlileri kirli, ayakkabısız ve neredeyse gömleksiz temsil ettiğinden dolayı; Appalaş'lara giden bir fotoğrafçı yerlilerden ayakkabılarını çıkarmalarını istemiştir (Dutton, 2013: 165).

18. Porno sektöründe de dolmuşçu, tamirci, pizzacı gibi meslekler üzerinden kurgular üretilmektedirler.

19. 04.02.2019 tarihinde https://www.meleklermekani.com/threads/koca-parasi.152129/adresinden alınmıştır.

20. 04.02.2019 tarihinde http://sosyobaz.com/sizleri-tebessum-ettirecek-en-komik-vergi-karikaturleri adresinden alınmıştır.

21. Bu kategoriler haberlerde yer aldığı şekliyle verilmiştir. 
Atıf: Öksüz, M., Deniz, A. (2019). Monotyping Gender, Place and Time: A Study on Rape Caricatures and Real Life Portrayals, Coğrafi Bilimler Dergisil Turkish Journal of Geographical Sciences, 17(1), 170-192, doi: 10.33688/aucbd.559283

\section{Coğrafi Bilimler Dergisi}

Turkish Journal of Geographical Sciences e-ISSN:1308-9765

\section{Monotyping Gender, Place and Time: A Study on Rape Caricatures and Real Life Portrayals}

Muhammet Öksüz*a, Ayla Deniz ${ }^{\mathrm{b}}$

\section{EXTENDED ABSTRACT}

\section{Introduction}

This study focuses on the depiction of gender, place and time typologies in caricatures and news. The sociopolitical context which creates these typologies and depictions is also a focal point for this paper. Rape is not an arbitrary act of violence committed by one individual against another; it is a political act of coercion committed by members of a powerful class against those of a less powerful one (Donovan, 2016). The fact that most rape victims are female shows that political coercion is directed towards women, and they are seen as members of the society's less powerful class. This study also aims to initiate a debate on the production of such messages and social relationships. In order to deepen the debate, caricatures depicting rape scenes and true stories about victims from the news were reviewed. This also aimed to reveal the similarities and differences between fact and fiction. This study is different from previous research (Okray, 2018) in that it evaluates caricatures and real life events simultaneously. The study has three parts: The first part describes rape, gender, place and time relationships in caricatures, while the second one shares an analysis of news about rape incidents in real life. Interpretations of these two sections may then be found in the conclusion which is the third part.

\section{Material and Method}

This study reviewed the years between 2013-2017 with no magazine or website limitation, and a total of 80 caricatures were ultimately examined. Of these, 30 which were directly related to rape were used in this context, while the remaining ones were used to position the typologies in rape caricatures. A total of 150 news about rape were examined to see how these incidents were presented to the public, even though the stories did not fully reflect the truth. The website of the daily newspaper Hürriyet was the chosen news outlet. The reason for selecting one newspaper only, while the cartoon sampling came from a variety of magazines, was that news appears in the same way in different papers. Therefore, Hürriyet was chosen as it is the daily with Turkey's highest circulation. Rapes from the newspaper were reviewed to cover the years 2009, 2011 and 2015. These three years were selected as they witnessed the rape and murder of three women: Münevver Karabulut, Sema Karakoca and

\footnotetext{
*Corresponding Author: muhammetoksuz@ siirt.edu.tr

${ }^{a}$ Siirt University, Department of Geography, Siirt/Turkey, https://orcid.org/0000-0002-2255-3111

b Ankara University, Department of Geography, Ankara/Turkey, https://orcid.org/0000-0001-5964-0131
} 
Özgecan Arslan. These incidents led to a prominence of rape news in the public eye during these years.

\section{Gender, Place and Time in Caricatures}

Gender Typologies

In $78 \%$ of the caricatures, men are portrayed as being dark, hairy and long-nosed. They have a big belly and thick eyebrows that meet in the middle. Among these, $22 \%$ are portrayed as muscular and big-toothed. Of the representations of women, $83 \%$ are heavily made-up, fair-skinned and haired; have a large bosom and hips; and are wearing either shorts or a miniskirt. Further, in $17 \%$ of these caricatures, women are shown to be wearing high heels. The typologies in these caricatures not only create the perception that it is these types of people who become perpetrators/victims, but they also cause other perpetrators/victims outside these typologies to be overlooked.

The men depicted in the caricatures as the perpetrators of rape are also older than the women. This suggests a relationship between youth and becoming a rape victim, and the idea that older women may be at a smaller risk when it comes to rape. At the same time, the caricatures do not offer any clues about what these young women's jobs are, and why they may be at that specific location at that time. Assault on women is depicted as targeting their simple presence in the street. That is probably why there are no caricatures depicting the raping of a woman at work. Women are also represented in fewer leadership roles than men (Streicher, 1974: 125-129) and as being docile and fragile (Thompson and Zerbinos, 1995: 68). Men, on the other hand, are more aggressive than women (Oliver and Stephen 2001: 68). There are caricatures which suggest that males with these characteristics commit rape without reasoning or will. Depicting men who become sexually aroused in caricatures when they meet the female typology of a rape victim suggests that it is women who are responsible for the rape, not the men. Indeed, the myth of the seductive woman and the controlling man in the Yusuf Sura (Ilkaracan, 2015: 18) is culturally parallel to this proposition. Women who do not fit with the typology in the caricatures are not viewed as seductive and, therefore, not depicted as a rape victim. Finally, regarding the relationship between perpetrators and victims, they are portrayed as strangers encountering each other for the first time.

\section{Place}

Forty-seven per cent of the places used in the caricatures depicting rape were set in forested areas, $26 \%$ in poor neighborhoods, $20 \%$ in parks and gardens behind buildings, and $7 \%$ on buses. As can be seen, the subtext is that rape only happens in public places. Among these, forests, poor neighborhoods, parks and gardens make a reference to the nature. These places are protected areas within cities, and they suggest being trapped between the nature and man-made designs. These locations present what is wild as being in the nature and doing its job. It is hungry and hunting. The places of rape depicted in caricatures also include poor neighborhoods. When such neighborhoods in cities and their inhabitants are studied, it is mostly with respect to their failure in adapting to urban life and migration from the country (settlements closest to the nature). Therefore, poor neighborhoods as a 
location for rape correspond to the nature and the wild; they are hunting places as well and are presented as requiring domestication. The references in these caricatures to the nature therefore serve to make rape familiar and natural.

Time

Eighty-three per cent of rape caricatures depict the time of rape as night; $10 \%$ do not depict a specific time; and 7\% depict daytime. Men, who own daytime, are also represented as the owners of the night. Having the sole control of time, the patriarchal man is always ready any time of the day. In this sense, the power and management of time has not been reversed in caricatures. On the other hand, women's time is restricted, just as their physical places. The patriarchal tradition dictates where they can be and what they can be doing at any given time during the day. On the other hand, the ontology of the night transforms into a symbolic label when those who go out at night, and are not heterosexual males, are labeled as the 'other' (sex worker, 'loose woman' etc.). According to this view, a woman who goes out at night risks much. The social values attributed to day and night lead to gendered time by differentiating day and night in our semantic worlds. Gendered time temporally fragments place.

\section{Representation of Reality: Gender, Place and Time in News}

In news about rape, $21 \%$ of victims were students, $29 \%$ were children, $11 \%$ were café workers, $8 \%$ were disabled individuals, and $8 \%$ were workers. The victims in the news representations varied more than those in the caricatures. Of the perpetrators, $11 \%$ were teachers, $9 \%$ drivers, $7 \%$ academics, $7 \%$ workers, $7 \%$ imams, $5 \%$ businessmen, $5 \%$ students, and $5 \%$ were policemen. The perpetrators also displayed variety. It may be seen from the same news that victims were less varied than perpetrators. On the other hand, the physical characteristics of victims and perpetrators varied greatly.

The news about rape was set in 28 different places. Twenty-nine per cent of the news was set in the perpetrators' houses and $11 \%$ in the victims' houses. A consideration of these places reveals the following: Of these places, 59\% belonged to the perpetrator, $12 \%$ belonged to the victims, and $29 \%$ were public places. While places that belonged to the perpetrators and victims comprised $71 \%$ of all places related to rape, public places comprised $29 \%$. In other words, $71 \%$ of rapes happen in private places. The time of rape incidents, on the other hand, seemed to be different. It was found that $45 \%$ of rapes mentioned in the news happened at night and 55\% during daytime.

Other than these, the relationship between the perpetrator and the victim is another important element. The relationships depicted in news formed 26 different categories. These categories were combined and reduced into five: Nuclear family 5\%, extended family $10 \%$, distant acquaintance $43 \%$, person from the social environment $28 \%$, and total stranger $13 \%$. Further reduced into two categories, these would be acquaintances (Nuclear Family-Extended Family-Social Environment) 87\% and total stranger $13 \%$. As can be seen, rape mostly happens in one's closest environment and seems to become less common in the public realm 


\section{Conclusion: Escape from Reality}

The present study, which centers on the representations of rape caricatures and their relationship to real life, has shown that the male perpetrator types drawn in caricatures do not fully match the typology revealed by true news. While the caricatures depicted most perpetrators as men from the lower class, the news included more perpetrators from the middle and upper classes. The same is also true for victims. Indeed, while the victims in the caricatures were mostly urban women from the middle and upper classes, the news revealed that many women from the lower class also became victims of rape. On the other hand, rape incidents involving disabled individuals and children mean that increased fragility also increases the probability of being raped. Also, while caricatures linked perpetrators and victims to certain professions, the true of rape recounted in news presented perpetrators and victims from more varied professional backgrounds. This reveals that the stereotypes in caricatures do not always correspond to real life. Another finding of the study has been that the time in caricatures differs from that in news. While the caricatures mostly referred to night time as the time of rape, news showed that there are many daytime rape incidents. In addition, the news stories did not confirm the caricatures regarding their portrayal of rape mostly happening in public places. According to the news, rape incidents frequently happened in private places blessed by security. What is more, the true relationship between the perpetrator and the victim in the private place was the exact opposite of the portrayal in the caricatures. While the latter usually portrays rape as happening between strangers, the former shows that rape mostly occurs between people related to one another in some way. Owing to these reasons, it may be concluded that caricatures, which associate rape with certain types, times and places, do not serve to reveal the typologies, places and times of real life rape incidents.

\section{Referanslar/References}

Alkan, A. (2005). Yerel Yönetimler ve Cinsiyet: Kadınların Kentte Görünmez Varlığı. Ankara Araştırması. Dipnot Yayınları.

Al-Mahadin, S. (2003). Gender Representations and Stereotypes in Cartoons: A Jordanian Case Study. Feminist Media Studies, 3(2), 131-151. doi:10.1080/1468077032000119281

Alsaç, Ü. (1994). Türkiye'de Karikatür Çizgi Roman ve Çizgi Film. İstanbul: İletişim Yayınları.

Altuntaş, H. Ş. M. (2007). Kuran-ı Kerim Meali-Diyanet İ̧sleri Başkanlı̆̆l, Ankara: Özgün Matbaacılık.

Amed, S. (2015). Duyguların Kültürel Politikası. Sel Yayıncılık

Balibar, E.,Wallerstein, I. (2017). Irk Ulus Sinıf: Belirsiz Kimlikler. İstanbul: Metis Yayınları.

Banks, A., Dwight B., Karen, T. (1993). Appalachian Studies, Resistance and Postmodernism. Stephen L. Fisher (Ed.). Appalachia: Traditions of Resistance and Change içinde. Philadelphia: Temple University Press.

Becker, H. S. (2015). Haricîler (Outsiders): Bir Sapkınlık Sosyolojisi Çalışması. Ankara: Heretik Yayınları.

Berktay, F. (2016). Tek Tanrılı Dinler Karşısında Kadın. İstanbul: Metis Yayınları.

Bobo J (1992). The Politics of Interpretation: Black Critics, Filmmakers, Audiences. Gina Dent (Ed.) Black Popular Culture içinde Seattle: Bay Press.

Bohner, G.,Danner, U. N., Siebler, F., Samson, G. B. (2002). Rape Myth Acceptance and Judgments of Vulnerability to Sexual Assault. An Internet Experiment. Experimental Psychology, 49(4), 257-269.doi: 10.1026//1618-3169.49.4.257

Bohner, G., Reinhard, M. A., Rutz, S., Sturm, S., Kerschbaum, B., Effler, D. (1998). Rape Myths as Neutralizing Cognitions: Evidence for A Causal İmpact of Anti-Victim Attitudes on Men's Self-Reported Likelihood of Raping. European 
Journal of Social Psychology, 28, 257-268. doi: 10.1002/(SICI)1099-0992(199803/04)

Bolt, M.,Caswell, J. (1981). Attribution of Responsibility to a Rape Victim. The Journal of Social Psychology, 114(1), 137138.doi: 10.1080/00224545.1981.9922739

Burt, M. R. (1980).Cultural Myths and Support for Rape. Journal of Personality and Social Psychology, 38(2), 217-230. doi: 10.1037/0022-3514.38.2.217

Cantek, F.Ş. Ulutaş, Ünlütürk, Ç. Çakmak, S. (2017). Evin İçindeki Sokak, Sokağın İçindeki Ev: Kamusal İle Özel Arasında Kalanlar. Funda Şenol Cantek (Ed.), Kenarın Kitabı içinde. 121-159. İstanbul: İletişim Yayınları.

Donnan, H., Wilson, T. M. (2002). Sinırlar: Kimlik, Ulus ve Devletin Uçları. Ütopya.

Donovan, J. (2016). Feminist Teori. İstanbul: İletişim Yayınları

Dünya Sağl1k Örgütü (WHO) (2002). World Report on Violence and Health. Etienne G. Krug, Linda L. Dahlberg, James A. Mercy, Anthony B. Zwiand Rafael Lozano (Ed.) WHO Library Cataloguing içinde Publication Data. doi: 10.1016/S0140-6736(02)11133-0

Düvenci, N. (2004). Cinsel Suçlar ve Kadın Mağdurun Korunması. 02.03.2019 tarihinde https://bianet.org/bianet/kadin/47797-cinsel-suclar-ve-kadin-magdurun-korunmasi adresinden alınmıştır.

Eker, T., Erdener, A. (2011).Tecavüze İlişkin Kültürel Mitler ve Mitlerin Kabul Edilmesine Etki Eden Faktörler. Türk Psikoloji Yazllarl, 14 (28), 60-72.

Foucault, M. (2016). Cinselliğin Tarihi. İstanbul: Ayrıntı Yayınları

Godenzi, A. (1992).Cinsel Şiddet. İstanbul: Ayrıntı Yayınları.

Goffman, E. (2018). Günlük Yaşamda Benliğin Sunumu. İstanbul: Metis Yayınları.

Göle, N. (2016). Modern Mahrem: Medeniyet Ve Örtünme. İstanbul: Metis Yayınları.

Hilav, S. (1994). Mizahın Evrimi ve Karikatür. Gül Diken: Dört Aylık Mizah Kültürü Dergisi. İris Yayınc1lık

Hurst, C. E., Gibbon, H. M. F., Nurse, A. M. (2016). Social Inequality: Forms, Causes, and Consequences. Routledge. doi: $10.4324 / 9781315536859$

İlkkaracan, P. (2015). Giriş: Müslüman Toplumlarda Kadın ve Cinsellik. Pınar İlkaracan (Ed.), Müslüman Toplumlarda Kadın ve Cinsellik içinde, İletişim Yayınları

Kar, İ (1999). Karikatür Sanatı. Ankara: TC. Kültür Bakanlığı Yayınları.

Karacan, O. (2015). Olguda Seçicilik: Tecavüzün Tanımlanması. Ankara Barosu Dergisi, 4, 109-118.

Karakuş, N. (2012). Medyada İntiharın Temsili: Karikatürde İntihar. Ankara: Ankara Üniversitesi Sağlık Bilimleri Enstitüsü Yayınlanmamıș Yüksek Lisans Tezi, Ankara. https://tez.yok.gov.tr/UlusalTezMerkezi/tezSorguSonucYeni.jsp adresinden edinilmiştir.

Kırbaş Canikoğlu, S. (2013). Feminist Bir Perspektifle Türk Ceza Kanunu'nda Cinsel Saldırı Suçu, Fe Dergi, 5 (1), 61-73.

Kitabı Mukaddes (1988). Eski ve Yeni Ahit (Tevrat Zebur ve Incil). İstanbul: Kitâb-1 Mukaddes Şirketi

Kopper, B. A. (1996). Gender, Gender Identity, Rape Myth Acceptance, and Time of Initial Resistance on the Perception of Acquaintance Rape Blame and Avoid Ability. Sex Roles, 34 (1-2), 81-93.

Koss, M, P.,Heise, L. Russo, N, F. (1997). The Global Health Burden of Rape. Gender Violence. New York and London, New York University Press, 233. doi: 10.1111/j.1471-6402.1994.tb01046.x

Küçük, B., Türkmen, B. (2017). Müzakeresiz Kamusallı: Milli Cemaatin Yeniden İnşası Sürecinde Demokrasi Nöbetleri. Toplum ve Bilim, 140, 181-214.

Lefebvre, H. (2016). Mekânın Üretimi. Sel Yayıncılık.

Lerner, G. (1986). The Creation of Patriarchy. ABD: Oxford University Press.

Mackinnon, C. (2003). Feminist Bir Devlet Kuramına Doğru. İstanbul: Metis Yayınları.

Mehrhof, B., Kearon, P. (1973) . Rape: An Act of Terror. Radical Feminism. Quadrangle: New York Times Book.

Okray, Z. (2018).Türk Basınında Kadına Yönelik Tecavüz Haberlerinin Eleștirel Söylem Çözümlemesi Modeliyle İncelenmesi. Sosyoloji Araştırmaları Dergisi, 21 (1), 190-238. 
Oliver M. B., Stephen G. (2001). Development of Gender Differences in Children's Responses to Animated Entertainment. Plenum Publishing Corporation.

Özbay, F. (2017). Dünden Bugüne Aile Kent ve Nüfus. İstanbul: İletişim Yayınları.

Özdemir, O. (2010).Bir İktidar Tekniği Olarak Kadına Yönelik Tecavüz Tehdidi. Ankara Üniversitesi Sosyal Bilimler Enstitüsü. Yayınlanmamış Yüksek Lisans Tezi, Ankara.

https://tez.yok.gov.tr/UlusalTezMerkezi/tezSorguSonucYeni.jsp adresinden edinilmiştir.

Park, R. E., Burgess, E. W. (2012). The City: SuggestionsforInvestigation of Human Behavior in the Urban Environment (Heritage of Sociology Series). University of Chicago Press.

Payne, D., L., Lonsway, K., A., Fitzgerald, L., F. (1999).Rape Myth Acceptance: Exploration of its Structure and its Measurement Using the Iillinois Rape Myth Acceptance Scale. Journal of Research in Personality, 33, 27-68.doi: 10.1006/jrpe.1998.2238

Pilgrim, D. (2000). The Coon Caricature. 04.02.2019 tarihinde http://www.ferris.edu/htmls/news/jimcrow/coon adresinden edinilmiştir.

Poppen, P. J., Segal, N. J. (1988). The Influence of Sex and Sex Role Orientation on Sexual Coercion. Sex Roles, 19 (11-12), 689-701.

Radford, J. (1987). Policing Male Violence- Policing Women. Jalna Hanmer, Mary Maynard (Ed.), Women, Violence and Social Control içinde Londra, Macmillan Press.

Ross, S. (1974). Caricature. The Monist, Oxford University Press, 58 (2), 285-293. doi: 10.1093/monist/onv036

Shoham, S. G., Hoffmann, J. P. (1991). A Primer in the Sociology of Crime. New York: Harrow and Heston Publishers.

Smith, G. (1996). Madam and Eve: A Caricature of Black Women's Subjectivity? Agenda, 12 (31), 33-39.

Stavrides, S. (2016). Kentsel Heterotopya, Özgürleşme Mekânı Olarak Eşikler Kentine Doğru. Sel Yayıncılık

Streicher, H. W. (1974).The Girls in the Cartoons. Journal of Communication, 24 (2), 125 129.doi: 10.1111/j.14602466.1974.tb00377.x

Şahin, Ü. (2014). Çizginin Gücü: Karikatür ve Sansür, 04.02.2019 tarihinde http://www.umut.org.tr/userfiles/files/Document/document_ca5f01b9796a40f782b43262be5fd0a9.pdf adresinden edinilmiștir.

Thompson T. L., Zerbinos E. (1995). Gender Roles in Animated Cartoons: Has the Picture Changed in 20 Years. Plenum, Publishing Corporation.

Tülü, İ. A.( 2010).Tecavüz Suçlularında ve Çocuk Cinsel İstismarcılarında Suç Analizi. Ankara Üniversitesi Sağlık Bilimleri Enstitüsü, Yayınlanmamış Yüksek Lisans Tezi, Ankara.

https://tez.yok.gov.tr/UlusalTezMerkezi/tezSorguSonucYeni.jsp adresinden edinilmiştir.

Uğur, A. (2013). Denizli Şehrinde Mala Karşı İşlenen Suçların Mekânsal Analizi. Polis Bilimleri Dergisi, 15(2), 1-37.

Uzun, A., Aliağaoğlu, A. (2009). Tokat Şehrinde Mala Karşı Suçlar, Uluslararası Sosyal Araştırmalar Dergisi, 2(8), 430444.

Üresinler, R. (2005). Sosyo-Kültürel Yapı ve Suç (Kırıkkale Örneği). Kırıkkale Üniversitesi, Sosyal Bilimler Enstitüsü, Yayınlanmamış Yüksek Lisans Tezi, Kırıkkale. https://tez.yok.gov.tr/UlusalTezMerkezi/tezSorguSonucYeni.jsp adresinden edinilmiştir.

Wikstrom, P. O. H. (1995). Preventing City Center, Street Crime. Crime and Justice, University of Chicago Press 19, 429468.

Williamson, J. W. (1995). Hillbillyland: What the Movies did to the Mountains and What the Mountains did to the Movies. UNC Press Books.

Yancı, F., Alioğlu, F., Polat, A. (2018). Tecavüze İlişkin Suçlayıcı Tutumlar ve Tecavüz Mitlerinin Farklı Değişkenle Açısından İncelenmesi. The Journal of Neuro Behavioral Sciences. (5) 2, 106-114

Yengin, D. (2010). İletişim Aracı Olarak Karikatürde "Komik Şiddet" Kullanımı. III. Ulusal İletişim Kongresi, Gülmenin Arkeolojisi ve Medyada Mizah Olgusu, 335-342.

Yücel, A. (2018). Feminist Kahkahanın Ötesinde: Karikatür Sanatı İçin Dişil Öznellik Bağlamında Bir Yöntem Önerisi. 
Maltepe Üniversitesi Sosyal Bilimler Enstitüsü. Yayınlanmamış Doktora Tezi, İstanbul. https://tez.yok.gov.tr/UlusalTezMerkezi/tezSorguSonucYeni.jsp adresinden edinilmiştir. 